\title{
CAFÉ AS STUDENT'S INFORMAL LEARNING SPACE: A CASE STUDY IN BANDUNG, INDONESIA
}

\author{
Samuel Sri Kurnia Adityawirawan ${ }^{1 *}$, Hanson E. Kusuma ${ }^{1}$ \\ ${ }^{1}$ School of Architecture, Planning, and Policy Development, Bandung Institute of Technology, Indonesia \\ Institut Teknologi Bandung (ITB, Bandung Institute of Technology), Jl. Ganesha No.10, Lb. Siliwangi, Kecamatan Coblong, \\ Kota Bandung, Jawa Barat 40132, INDONESIA \\ *Corresponding author; Email: samuel7.sama@gmail.com
}

\begin{abstract}
For the past years, the café's functionality has shifted from serving light food or beverages to being used by students as an informal learning space (ILS). This paper discusses university student's motivation to study in a café and the desired café's characteristics as an ILS in Bandung, Indonesia. The research uses a quantitative method using a questionnaire to reveal the dimensions of students' internal motivation and spatial characteristics of the café and its effect on students' informal learning responses while in the café. Results found 6 (six) groups of student motivations and 7 (seven) characteristics of cafés as an ILS. Results uncover a positive relationship between utilitarian motivation and physical characteristics in the form of the availability and quality of café amenities on students' cognitive and affective responses. It is implied that students choose a café as an ILS because such informal space can provide satisfactory physical amenities so that their learning performance is expected to increase. Through this trend, universities and/or related stakeholders could use this opportunity to improve the well-being of the student.
\end{abstract}

Keywords: Bandung, café; escapism; informal learning; student.

\section{INTRODUCTION}

Nowadays, learning activities can be done anywhere and anytime, which gives rise to informal learning spaces in several sectors of educational institutions. From a formal education perspective, the phenomenon is pushing educational institutions to be more flexible and adaptive. On the other perspective, technological developments also have an impact on student learning behavior. Abeysekera and Dawson's (2015) findings conclude that learning activities can occur outside the formal system in traditional schools. The learning process that can be done by watching video lectures at home, riding public transportation, sitting in the cafés, or in the park is referred to as the concept of a flipped classroom. This term is further popularized as informal learning space (ILS) by Walton and Matthews (2018). The location of the ILS itself can be divided based on the needs of students, where the house tends to be used as a private learning space (individual activity), and spaces within the university are mostly used by students to work in groups (Beckers, 2016). In general, places that students can use as informal learning spaces have also been classified by Beckers (2015) into 4 (four) ranges as seen in Fig 1.

In Indonesia, one of the informal learning spaces commonly found are cafés for study spaces by students. This shows that cafés have transformed their functions as informal spaces; and, in the context of architecture, have become a new informal learning space. One source of this phenomenon is the process of the commodification of historical buildings into commercial areas such as cafés or co-working spaces Gantini, 2018). Through this, new activities arise involving culinary culture, one of which is the culture of working individually but together with others around it (co-working). This phenomenon is reinforced through several previous studies, which found that informal learning spaces on campus began to be integrated with cafés or eating places (Oblinger, 2006; Boys, 2011). The phenomenon of the use of cafés by students as a learning space is understandable, because at present, most cafés not only sell coffee or snacks but also provide space for refreshing (Ward, 2018). In Harrop and Turpin (2013) research,

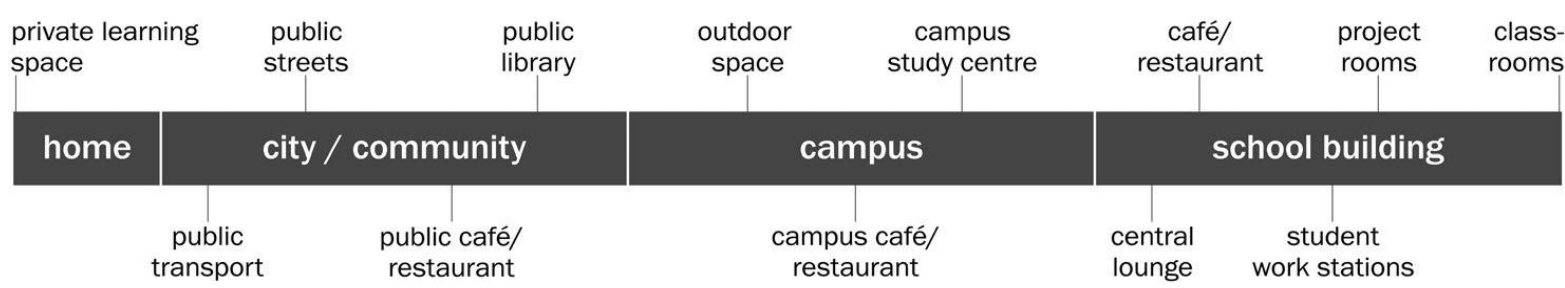

Fig. 1. Conceptual mapping for learning space preferences (Source: Beckers, 2015) 
refreshments are seen as crucial to an informal learning space because they not only provide benefits for those who are studying or resting, but café or dining rooms also provide stimulus and create an atmosphere that can enhance the students' spirit. This paper will look for students' behavior for choosing a café as an ILS through their motivation and the café's spatial characteristics. A case study in Bandung was chosen because of the growing number of café or coffee shops in the recent five years (Bandung Culture \& Tourism Agency, 2019).

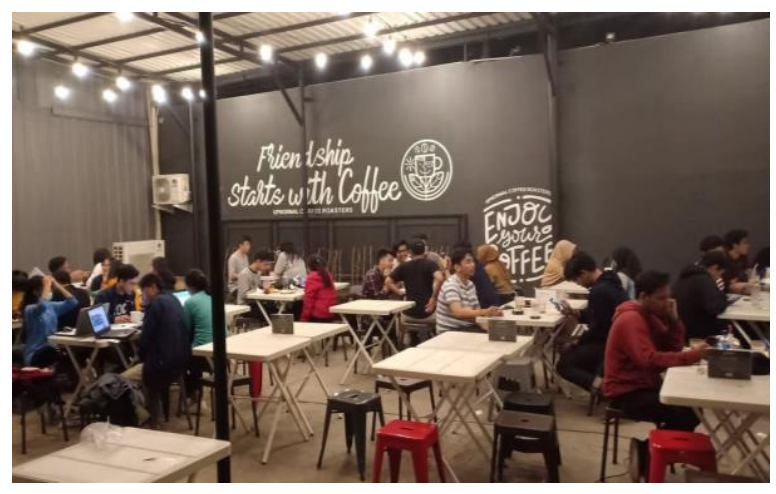

Fig. 2. Students are using the café main dining area as a place in working their assignment in laptop, or discussing within a small group of people (2-4 person)

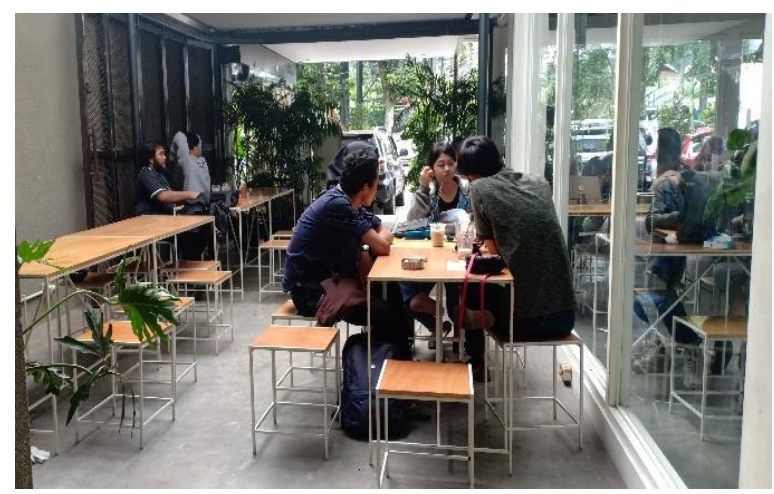

Fig. 3. Students are using the outside area of the café, mostly for group-based learning

The study will discuss the dimensions of internal encouragement that make students shift their learning processes into the café space. Based on the café function as a retail shop, the usage of hedonic shopping motivations (Arnold and Reynolds, 2003) was used in this research. In addition to those six motivations, a study conducted by Kim (2005) also extracted two utilitarian motivations from basic consumer behavior, namely efficiency and achievement motivations. This research would uncover students' primary motivation, whether it's purely utilitarian or hedonistic, in using café as an ILS with these eight shopping motivations.
It will also discuss the dimensions of the spatial characteristics of cafés that are formed on physical and social characteristics, similar to the dimensions of informal learning spaces in general. These spaces can be further explained as a learning space by incurporating other aspects, i.e., social characteristics (Beckers, 2016) of cafés. Similar to cafés, co-working space used by students also needs to be examined to see whether there are similarities between the two types of spaces. Therefore, research on the characteristics of cafés as ILS needs to be done.

Specifically, learning responses in informal spaces are reviewed through the type of reading activities in Tampubolon research (2017). There are three main concerns, namely cognitive, affective, and student behavior. Findings on these two dimension groups will be linked to student learning responses, both in terms of cognitive (understanding) and affective (feeling). Those three variables will be used to check students' perceptions during the ILS process in the café. Afterward, an analysis will be conducted to see whether there is a connection between students' internal motivation or the café's spatial characteristics to the student's performances. This analysis will fill the missing link of students' responses during the informal learning process in the body knowledge of learning space in general.

\section{LITERATURE REVIEW}

\section{Café Growth in Bandung, Indonesia}

The city of Bandung itself is one of the regions in West Java Province, Indonesia, experiencing a large increase in the number of cafés. Data from the City of Bandung Culture \& Tourism Agency shows that there were 396 cafés in 2017 in the city of Bandung. This number does not include cafés or other restaurants that do not have a permit (Bandung Culture \& Tourism Agency, 2019).

Over time, the function of the café has shifted from the place for consuming food and drinks to the fulfillment of other pleasures and activities (informal). Photography and social media activities to share moments become a motivating factor for someone to visit a café as a lifestyle (Farasa \& Kusuma, 2015; Gantini, 2018). With a large number of cafés in Bandung, business competition occurs through the display of the visual characteristics of buildings, food variations, or adequate facilities of a café (Farasa \& Kusuma, 2015; Astuti, 2015). Cafés or eating places are also found to be spaces with high levels of feeling at home for students to read (Tampubolon, 2016). Researches conducted in the last five years have shown that there is a change in motivation to visit cafés besides to consume food and drinks. 
Café space in Bandung is increasingly similar to co-working space which has also been rife in recent years. This space is different from a multi-tenant office because co-working here is not only a place to work, but it also creates a mutual transfer of knowledge to the community. Co-working space refers to individual activities carried out together in a particular environment (Gandini, 2015). It also has values as the basis for shaping its community, namely collaboration, openness, community, sustainability, and accessibility (Kwiatkowski \& Buczynski, 2011). Similar to cafés and restaurants, some co-working spaces in the city of Bandung have dining spaces as their primary areas. Dining space is meant to be the criteria in the first layer in designing a co-working space in terms of commercial (Bouncken, 2016).

\section{Student's Shopping Motivation}

Understanding of motivation refers to the text described by Solomon (2018), which is a set of processes that encourage someone to behave as they should. This happens when someone has a passion for satisfying their desires. This need makes a person reduce or eliminate the pressure that arises due to these desires. Emerging needs can be utilitarian (the desire to benefit functionally or practically) or hedonic (experimental needs, which involve feelings or fantasies). Research on these two main categories has also been carried out before, which ultimately pursed these two groups into shopping motivation Bloch \& Richins, 1983; Westbrook \& Black, 1985). This study uses two shopping motivation groups as a basis for student motivation search because motivation has not been found to be directly related to informal learning. Furthermore, motivation to use a café as an ILS can be seen as a condition where a person has a need to simply find a place to work (utilitarian) or use space while enjoying the atmosphere and products offered (hedonistic).

The hedonistic motivation category is a positive experience that one feels emotional regardless of the number of purchases made. Arnold and Reynolds (2003) have suggested six types of hedonistic motivation in shopping, namely: adventure, social, gratification, ideas, roles, and value. Motivation is the feeling of adventure to shop while looking for experiences, stimulation, or new stimuli. Social motivation emphasizes the purpose of shopping with family or friends. The motivation of gratuity refers to a person's ability to give a decent gift for oneself. Rolebased motivation is the feeling when someone buys a product for someone else. While the value motivation is the goal of someone shopping to look for discounts and other offers.
In contrast to the six hedonistic motivational points, utilitarian motivation is divided into two types by Kim (2005), namely efficiency and achievement. Efficiency-based motivation is a person's shopping destination to save time. While the achievement is a shopping motivation carried out with the aim of finding products that are planned to be purchased. Through this, it can be concluded that the utilitarian aspect is the motivation of consumers to seek satisfaction based on one's functions and needs.

The selection of shopping motivation in this Study was conducted to see the relationship between a person's motivation when using a café as an informal learning space. The motivation that is focused on learning needs is still not widely found, so researchers decided to look for motivation through hedonistic and utilitarian shopping motivation that has been studied previously. The adjustment between the items of the questionnaire regarding shopping motivation is adjusted to the learning needs of students.

\section{Characteristics of Informal Learning Space}

Informal Learning Space (ILS) to be discussed in this research refers to the understanding of Jamieson (2008), who explained that ILS is a set of networks of experience and interaction, which includes the physical environment, from internal to external spaces such as classrooms, cafés, plazas, or libraries. The knowledge transferred in this ILS is not done from the teacher to his students but is formed from each individual through active social processes with others. With the development of the virtual world today, a person can access learning materials from anywhere so that learning space is not limited to school buildings. Beckers et al. (2016) agree with Harrison (2002), where the analogy 'city is the office' (the city is the office) indicates that every square meter formed from a built environment has the potential to support one's learning activities.

In Bickford \& Wright's (2006) research, the implications of student activities shape the type of space they need. For example, the need for students to be able to study wherever and whenever can be accommodated through public or residential spaces, such as libraries. This type of space allows one to study, taking into account wireless installations for information networks, lighting control, sound, and security. Club or organizational activities involving dialogue between students are accommodated in an attractive, comfortable, and flexible space. Student collaborative learning activities can also be accommodated through public spaces in the form of a dining area or foyer. Rooms like this are more spacious, attractive, and accessible when students need to meet. This informal learning activity has an impact on the emergence of informal spaces. 


\section{Student's Response in Informal Learning}

Research from Tampubolon (2017) formulates student learning responses into three groups, namely cognitive, affective, and behavioral. The cognitive response is one's comprehension ability in the learning process. In the context of educational buildings, several studies have found that heat, lighting, and noise affect one's cognitive abilities. The affective response is related to the psychology and feelings of users while in a room. Behavior is associated with the duration of learning, duration of use of ILS, and intensity of visits to the ILS. In the same study, it was shown that informal learning spaces have an influence on student performance in general. The research uses the three responses as described to comprehensively examine the impact of ILS in using cafés.

\section{METHODOLOGY}

This research used a quantitative research paradigm (Kumar, 2005) and was conducted in 1 phase, in which researchers took samples through a questionnaire to several respondents. The data collected were numerical data and will be analyzed to find relevant latent dimensions that represent students' motivation, the café's spatial characteristics, and student's responses in the ILS. Students' motivations and café's spatial characteristics will be used as independent variables, while student's responses will act as a dependent variable, in which the regression analysis will take place later to discover the dominant dimensions.

\section{Sample and Study Design}

The sample to be studied are students who are currently studying at a tertiary level in Bandung. The design of sampling in phase I is by distributing random online questionnaires to students via the internet (non random-purposive sampling). Sampling is also done by distributing random physical questionnaires to students who are the target sample. Students selected as samples are active students who are at least in the level II and maximum level IV at the undergraduate level. The limitation of the study year is done with the consideration that the student is already familiar with cafés in the city of Bandung and has conducted an informal learning process at least once.

The institutions chosen as the research sample are 4 (four) institutions that have a student population of over 9,000, according to data from the Central Statistics Agency of Bandung (2018). The four institutions are located in Bandung City, where Institu- tions $\mathrm{A}$ (105 respondents) and $\mathrm{C}$ (71 respondents) are located in the Coblong sub-district, Institution B (136 respondents) in Sukasari sub-district, and Institution D (85 respondents) in the Cidadap sub-district. (3) Sampling from four different institutions is also intended to find trends in cafés chosen by students in Bandung in general. A total of 397 respondents were collected for the data of this paper.

\section{Measures}

The variables in this study are divided into two categories, namely independent variable (free) and dependent variable (dependent). The independent variables in this study are ILS selection attributes, ILS physical characteristics, and social characteristics of ILS, whereas the dependent variable for this study was student responses which included cognitive, affective, and student response in activities.

\section{RESULTS AND DISCUSSION}

\section{Student's Motivation in Using Café as Ils}

Based on data collected through a questionnaire distributed between 25 February 2019 and 31 March 2019, there were 419 respondents obtained from 4 different institutional cases. Respondents consisted of 220 men (53\%) and 199 women (47\%) and were dominated by students with the 2017 class year (currently pursuing level II education), i.e., 201 students (48\%). There were 9 (nine) respondents from students of 2014 and 2 students from 2013, although the number was not significant.

Through 36 motivational variables using cafés as informal learning spaces, several motivational groups were found. The factor analysis process produces nine groups of latent motivational variables with eigenvalue values of more than 1 . However, this number is not used because the number of latent variables is too high (Zwick \& Velicer, 1986). Instead, the 6 latent variables with an eigenvalue of 1.3655 and cumulative percent of $53,336 \%$ were used, which grouping explained about $53 \%$ of the data from the entire population. The grouping of these six motivations also reduces statement items that have a loading factor of less than .50. The study uses a questionnaire distribution method to students who are currently in the environment of their respective institutions. This causes students' perceptions of the cafés they use an ILS to be biased. Nevertheless, the Cronbach alpha value for the average questionnaire results was found to be 0.73 . The results of the analysis of motivational group factors for using cafés as informal learning spaces for students can be seen in the following table 3 . 
Table 1. Table showing the detail of questionnaire's variables

\begin{tabular}{|c|c|c|c|c|}
\hline Variable Type & Variables & Operational Variables & Source & Scale \\
\hline \multirow{11}{*}{$\begin{array}{l}\text { Independent } \\
\text { Variable-- } \\
\text { Motivation for using } \\
\text { café as an ILS }\end{array}$} & Hedonistic & Adventure & (Arnold \& Reynolds, 2003) & Likert Scale 1-7, where \\
\hline & & Flow & Tiwari (2010) & 1 is strongly disagree, \\
\hline & & Gratification & (Arnold \& Reynolds, 2003) & and 7 is strongly agree \\
\hline & & Stimulation & Tiwari (2010) & \\
\hline & & Idea/Exploration & (Arnold \& Reynolds, 2003) & \\
\hline & & Value & (Arnold \& Reynolds, 2003) & \\
\hline & & Role & (Arnold \& Reynolds, 2003) & \\
\hline & & Social & (Arnold \& Reynolds, 2003) & \\
\hline & Utilitarian & Achievement & $\operatorname{Kim}(2005)$ & \\
\hline & & Efficiency & $\operatorname{Kim}(2005)$ & \\
\hline & Time & Timely & Harrop Turpin (2013) & \\
\hline \multirow{23}{*}{$\begin{array}{l}\text { Independent } \\
\text { Variable-ILS } \\
\text { characteristics in } \\
\text { café }\end{array}$} & Comfort & Temperature & Beckers (2016) & Likert Scale 1-7, where \\
\hline & & Lighting & Beckers (2016) & 1 is strongly disagree, \\
\hline & & Music background & Preceeding Study & and 7 is strongly agree \\
\hline & & Furniture & Beckers (2016) & \\
\hline & & ILS Size & Beckers (2016) & \\
\hline & Aesthetic & Decoration & Beckers (2016) & \\
\hline & & Plantation & Beckers (2016) & \\
\hline & Information \& & Computer & Beckers (2016) & \\
\hline & Communication & Wi-Fi & Beckers (2016), Bueno (2018) & \\
\hline & Technology (ICT) & & & \\
\hline & Layout & Availability to adjust furniture & Beckers (2016) & \\
\hline & & ILS locations & Beckers (2016) & \\
\hline & Naturalness & Temperature & Barrett (2015) & \\
\hline & & Lighting & Barrett (2015) & \\
\hline & & Accoustic & Barrett (2015) & \\
\hline & & Relationship with nature & Barrett (2015) & \\
\hline & Stimulation & Complexity & Barrett (2015) & \\
\hline & Privacy & Privacy & Beckers (2016) & Likert Scale 1-7, where \\
\hline & Interaction & Socialize with friends & Beckers (2016), Bueno (2018) & 1 is strongly disagree, \\
\hline & & Friend's appeanace & Bueno (2018) & and 7 is strongly agree \\
\hline & & Working together with peers & Bueno (2018) & \\
\hline & $\begin{array}{l}\text { Individualization, } \\
\text { Autonomy }\end{array}$ & Freedom to choose time needed & Beckers (2016) & \\
\hline & & Freedom to choose ILS location & Beckers (2016) & \\
\hline \multirow{5}{*}{$\begin{array}{l}\text { Dependent Variable } \\
\text { - Student's response }\end{array}$} & Cognitive & Understanding & Marchand (2016) & Likert Scale 1-7, where \\
\hline & Affective Response & Concentration & $\begin{array}{l}\text { Marchand (2016), Tampubolon } \\
\text { (2017) }\end{array}$ & $\begin{array}{l}1 \text { is strongly disagree, } \\
\text { and } 7 \text { is strongly agree }\end{array}$ \\
\hline & & Productivity based on quality & Bueno (2018) & \\
\hline & & Productivity based on time & Bueno (2018) & \\
\hline & & Mood & Tampubolon (2017) & \\
\hline
\end{tabular}

Table 2. Table showing the sample question with Likert scale

\begin{tabular}{llllllllll}
\hline \multicolumn{1}{c}{ What do you feel when you decided to study in a café? } \\
(Put a check mark $\sqrt{ }$ or circle $(\mathrm{O})$ on choice that you agree with) \\
\hline Studying in café feels like a recreation & Strongly Disagree & 1 & 2 & 3 & 4 & 5 & 6 & 7 & Strongly Agree \\
Studying in a café is my method to get rid of my stress & Strongly Disagree & 1 & 2 & 3 & 4 & 5 & 6 & 7 & Strongly Agree \\
I study at a café for the sake of socializing & Strongly Disagree & 1 & 2 & 3 & 4 & 5 & 6 & 7 & Strongly Agree \\
\hline
\end{tabular}

From the 36 variables of motivations that were significant to be grouped into latent dimensions, six new dimensions were found. These new motivation dimensions shared some similarities with the shopping motivations from the preceding research, whether it's hedonistic (Arnold \& Reynolds, 2003) or utilitarian (Kim, 2005). Motivation for restoration could be linked with gratification shopping motivation, where both share the similarity of treating oneself a positive feeling whenever their current state of mind is downed. Motivation for productivity could be seen as an amalgamation of utilitarian motives, where it is the only student's motives among the other five motives that revolve about how students expect they could meet their learning targets when using café as an ILS. Motivation for social identity shares similar points with adventure shopping and social shopping, another hedonistic motivation, where students could be seen to look for similar peers, most likely people who came to café for studying, so they could feel they are in the same shared universe. Motivation for novelty is similar to idea shopping, whereas students 
Table 3. Table showing the latent dimensions of student's motivation in using café as an ILS

\begin{tabular}{|c|c|c|c|c|c|}
\hline Variable & Dimension Name & Fac. Load. & $\alpha$ Cro. & Mean & Std. Dev \\
\hline Visiting café whenever feeling stressed & Motivation for & 0.76 & 0.65 & 4.53 & 1.20 \\
\hline Visiting café whenever feeling lonely & restoration & 0.71 & & & \\
\hline Visiting café whenever feeling bored & & 0.70 & & & \\
\hline Getting a feeling of relaxation & & 0.62 & & & \\
\hline Studying in café to make mood better & & 0.62 & & & \\
\hline Studying in café to get rid of stress & & 0.55 & & & \\
\hline Studying in café to treat oneself & & 0.54 & & & \\
\hline To finish study / assignments faster & Motivation for & 0.77 & 0.65 & 4.64 & 1.08 \\
\hline To increase productivity & productivity & 0.76 & & & \\
\hline To meet learning targets & & 0.75 & & & \\
\hline Getting a feeling of happiness if succeed in meeting learning targets & & 0.71 & & & \\
\hline Visiting café because of its long operating duration & & 0.57 & & & \\
\hline Saving energy while studying in café & & 0.53 & & & \\
\hline Getting a motivation/surge to learn & & 0.51 & & & \\
\hline To chat with waiters who were interested in the same thing & Motivation for social & 0.65 & 0.63 & 3.74 & 1.11 \\
\hline To meet other customers who have similar tastes & identity & 0.65 & & & \\
\hline To feel like an adventure & & 0.61 & & & \\
\hline To feel like a recreation & & 0.54 & & & \\
\hline To get an unforgettable experience by studying with others & & 0.52 & & & \\
\hline To enjoy new products (food/beverages) & Motivation for novelty & 0.74 & 0.70 & 3.89 & 1.19 \\
\hline To follow trends & & 0.65 & & & \\
\hline To get a new experience & & 0.56 & & & \\
\hline To enjoy discounts & Motivation for & 0.84 & 0.75 & 5.22 & 1.34 \\
\hline Because there was a discount at the café & economic price & 0.83 & & & \\
\hline To enjoy products at cheap prices & & 0.72 & & & \\
\hline To eat and drink with friends & Motivation for social & 0.62 & 0.68 & 4.98 & 1.06 \\
\hline To enjoy socializing with other people & interaction & 0.59 & & & \\
\hline
\end{tabular}

feel the need to study in a café as it has become quite a trend among the same generation nowadays. The motivation for economical prices holds the highest mean among all six motivations, so it could be interpreted that most of the students had the urge to study inside a café whenever they could afford the culinary products through discounts or low prices, similar to how to value shopping motivation is. Finally, motivation for social interaction shares the similarity with social shopping, but this motivation is rather active than how motivation for social identity works, given students feel the need to go to a café as a means To communicate, eat, or drink with their friends. Through the six motivations found, it can be concluded that motivation for economical prices holds the highest mean, followed by social interaction and productivity, respectively. In contrast, students did not seem to consider social identity as their highest priority when picking café as their ILS because of the lowest mean number. In general, these six students' motivations shared similarities with how shopping motivations affect a consumer, where students seem to be motivated by how the café presented their services through discounts and prices that are affordable by students.

\section{Spatial Characteristics of Café as ILS}

Through 23 variable characteristics of cafés as informal learning spaces, found several groups of spatial characteristics of café spaces were found. After conducting the factor analysis, author found 2 distinct latent dimension of a café's spatial characteristics. Thus, the characteristics of the café as an ILS was divided into two groups, namely physical characteristics and social characteristics. The factor analysis process of 16 variables produces four groups of physical characteristics with an eigenvalue of more than 1. Grouping produces 4 latent variables with an eigenvalue value of 1.1172 and a cumulative percentage of $62,013 \%$. The results of the factor analysis of the physical characteristics of the café as students' informal learning spaces can be seen in the following table 4.

While the scree plot method for social characteristics groups is also divided into as many as three pieces. The grouping of these 7 variables into 3 latent dimensions is also based on an eigenvalue of 1,017 which explains $80.81 \%$ of the data. The results of the factor analysis of social characteristics of cafés as informal learning spaces for students can be seen in the following table 5 . 
Table 4. Table showing the latent dimension of café's physical characteristic as an ILS

\begin{tabular}{|c|c|c|c|c|c|}
\hline Variable & Dimension Name & Fac. Load. & $\alpha$ Cro. & Mean & Std. Dev \\
\hline Seats in the café are comfortable to use & Café's amenity quality & 0.83 & 0.49 & 5.42 & 0.96 \\
\hline Tables in the café are comfortable to use & & 0.83 & & & \\
\hline Size of the room in café is spacey for extensive learning & & 0.69 & & & \\
\hline The sound of music in the café supports the learning atmosphere & & 0.65 & & & \\
\hline Artificial lighting (lamps) in the café is comfortable & & 0.57 & & & \\
\hline I can arrange tables and chairs freely while studying & & 0.56 & & & \\
\hline Air conditioner $(\mathrm{AC})$ temperature in the café is comfortable & & 0.54 & & & \\
\hline I can see the natural scenery in the café & Café's naturalness & 0.78 & 0.54 & 4.81 & 1.15 \\
\hline I rarely receive noise disturbances in the café & & 0.77 & & & \\
\hline Wind speed in the café is comfortable & & 0.62 & & & \\
\hline Natural lighting (sunlight) in the café is comfortable & & 0.53 & & & \\
\hline The decoration in the café suits my taste & Café's interior design & 0.81 & 0.60 & 4.95 & 1.14 \\
\hline The color of the wall in the café suits my taste & & 0.85 & & & \\
\hline Furnitures in the café provide appropriate visual diversity & & 0.57 & & & \\
\hline My laptop is very important when studying at the café & Information & 0.81 & 0.71 & 5.93 & 1.14 \\
\hline Fast Wi-Fi connection in café is very important to me when studying & $\begin{array}{l}\text { Communication } \\
\text { Technology (ICT) } \\
\text { Facility }\end{array}$ & 0.79 & & & \\
\hline
\end{tabular}

Table 5. Table showing the latent dimension of café's social characteristic as an ILS

\begin{tabular}{|c|c|c|c|c|c|}
\hline Variable & Dimension Name & Fac. Load. & a Cro. & Mean & Std. Dev \\
\hline I am free to choose a place to study in that café & Student's autonomy & 0.83 & 0.83 & 5.39 & 1.23 \\
\hline I am free to choose the time to study at the café & & 0.83 & & & \\
\hline My learning area in café is free from other people's distractions & & 0.54 & & & \\
\hline Discussions with customers in café make me comfortable in studying & Customer's presence & 0.78 & 0.83 & 3.66 & 1.63 \\
\hline The presence of customers in café makes me comfortable studying & & 0.53 & & & \\
\hline The presence of a friend in café makes me comfortable studying & Friend's presence & 0.81 & 0.79 & 5.37 & 1.26 \\
\hline
\end{tabular}

Spatial characteristics of an ILS can be further categorized into 7 distinct dimensions through the findings. These 7 dimensions also divided into 2 different groups, namely physical characteristics and social characteristics. Similar with the proceeding research about ILS characteristics done by Barrett (2015), Beckers (2016), and Bueno (2018), the 7 found dimensions seem to be almost identical. A café's amenity quality and their interior design mixed similar aspects from comfort and aesthetic characteristics of an ILS in general. Amenity quality defines the café as a proper ILS through the availability of comfortable furniture, such as tables, chairs, the size of the room, and also supported by appropriate music and lighting. While the interior design shapes the café as a suitable ILS through the use of decorations and wall color. Meanwhile, naturalness and information communication technology (ICT) facility appeared to be consistent compared with the proceeding research. Naturalness is how a café reacts to its surrounding, by giving the students access to view or feel the natural aspects outside the café, be it in a form of visual (scenery) or audial (noise). Given the highest mean rate among other physical characteristics, it should be noted that café's ICT facility seem to be the most prominent characteristics in making the café into an ILS. This concludes that students consider the availability of space required to use laptop or fast WiFi connection the most during the learning process.

On the other hand, the social characteristic of a café as an ILS is defined through the student's freedom to interact with objects that inhabits the café. The dimensions are quite similar with how Beckers (2016) identified, that is from the interaction and the autonomy inside an ILS. The result found that student's autonomy holds the most notable aspect among the three, with its highest rate. Student's flexibility to pick a table or seat in a café or how the location gives more privacy from other customer was important to be considered when using café as an ILS. The other dimensions that revolve around interaction are classified into 2 groups, which is friend's presence and customer's presence. It should be noted that friend's presence is more favorable than stranger, as it is shown to have higher mean rate than the latter.

In accordance with general classification, student response variables when using cafés as ILS are directly categorized into 2 factors, namely cognitive response and affective response. 
Table 6. Table showing the latent dimension of student's response during the usage of café as Informal Learning Space

\begin{tabular}{|c|c|c|c|c|c|}
\hline Variable & Dimension Name & Fac. Load. & $\alpha$ Cro. & Mean & Std. Dev \\
\hline I find it easier to concentrate when studying at the café & Cognitive Response & 0.88 & 0.91 & 4.79 & 1.30 \\
\hline I feel that I can improve the quality of my work when studying at the café & & 0.85 & & & \\
\hline I find it easier to understand the subjects when studying at the café & & 0.82 & & & \\
\hline I feel that I can finish my work faster when studying at the café & & 0.75 & & & \\
\hline I feel relaxed when studying at the café & Affective Response & 0.88 & 0.90 & 5.35 & 1.16 \\
\hline I feel comfortable when studying at the café & & 0.85 & & & \\
\hline If feel happy when studying at the café & & 0.84 & & & \\
\hline
\end{tabular}

Table 7. Table showing the regression analysis between student's motivation and café's spatial characteristic towards student's cognitive and affective response when studying in café as Informal Learning Space

\begin{tabular}{lcccccccc}
\hline \multirow{1}{*}{ Dimensions } & \multicolumn{4}{c}{ Cognitive } & \multicolumn{4}{c}{ Affective } \\
\cline { 2 - 9 } & Estimate & Std. Error & $\mathbf{t}$ Ratio & Prob>[t] & Estimate & Std. Error & t Ratio & Prob>[t] \\
\hline Intercept & $1.07 E-16$ & 0.04 & 0 & 1 & $-8.25 E-16$ & 0.043 & 0 & 1 \\
Motivation for restoration & $\mathbf{0 . 1 4}$ & $\mathbf{0 . 0 4}$ & $\mathbf{3 . 3 3}$ & $\mathbf{0 . 0 0 1}$ & $\mathbf{0 . 1 7}$ & $\mathbf{0 . 0 5}$ & $\mathbf{3 . 6 7}$ & $\mathbf{0 . 0 0 1}$ \\
Motivation for productivity & $\mathbf{0 . 3 7}$ & $\mathbf{0 . 0 5}$ & $\mathbf{8 . 1 6}$ & $<.0001$ & $\mathbf{0 . 1 7}$ & $\mathbf{0 . 0 5}$ & $\mathbf{3 . 5 0}$ & $\mathbf{0 . 0 0 1}$ \\
Motivation for social identity & $\mathbf{0 . 1 8}$ & $\mathbf{0 . 0 5}$ & $\mathbf{3 . 7 5}$ & $\mathbf{0 . 0 0 1}$ & -0.06 & 0.05 & -1.15 & 0.25 \\
Motivation for novelty & -0.01 & 0.04 & -0.17 & 0.86 & $\mathbf{- 0 . 1 3}$ & $\mathbf{0 . 0 4}$ & $\mathbf{- 3 . 0 1}$ & $\mathbf{0 . 0 0 1}$ \\
Motivation for economic price & $\mathbf{- 0 . 1 5}$ & $\mathbf{0 . 0 4}$ & $\mathbf{- 3 . 4 1}$ & $\mathbf{0 . 0 0 1}$ & 0.13 & 0.05 & 2.77 & 0.01 \\
Motivation for social interaction & -0.01 & 0.04 & -0.15 & 0.88 & 0.07 & 0.05 & 1.42 & 0.16 \\
Cafe''s amenity quality & $\mathbf{0 . 1 3}$ & $\mathbf{0 . 0 5}$ & $\mathbf{2 . 8 3}$ & $\mathbf{0 . 0 0 1}$ & $\mathbf{0 . 1 8}$ & $\mathbf{0 . 0 5}$ & $\mathbf{3 . 7 7}$ & $\mathbf{0 . 0 0 1}$ \\
Cafe's naturalness & $\mathbf{0 . 0 9}$ & $\mathbf{0 . 0 5}$ & $\mathbf{1 . 9 7}$ & $\mathbf{0 . 0 5}$ & 0.06 & 0.05 & 1.23 & 0.22 \\
Cafe's interior design & 0.01 & 0.04 & 0.16 & 0.87 & 0.12 & 0.05 & 2.54 & 0.01 \\
ICT Facility & 0.08 & 0.05 & 1.68 & 0.09 & 0.05 & 0.05 & 0.92 & 0.36 \\
User's autonomy & 0.00 & 0.05 & 0.02 & 0.99 & -0.03 & 0.06 & -0.56 & 0.58 \\
Customer's presence & 0.08 & 0.05 & 1.59 & 0.11 & 0.00 & 0.05 & -0.05 & 0.96 \\
Friends' presence & 0.03 & 0.05 & 0.69 & 0.49 & $\mathbf{0 . 1 5}$ & $\mathbf{0 . 0 5}$ & $\mathbf{3 . 0 6}$ & $\mathbf{0 . 0 0 1}$ \\
\hline
\end{tabular}

Unlike the preceeding research done by Tampubolon (2017) with 3 dimension of student's response, result revealed 2 distinct dimensions, namely cognitive and affective response. Similar with how the nature of shopping motivation (utilitarian and hedonistic), these 2 responses shared similar traits in common. Cognitive response is how students perceived the informal learning process in a café as a means to get their learning targets done. Meanwhile, affective response is how students experienced the whole process to refresh their mood. Given the higher mean rate than the former, most of students felt greater affective response during an informal learning process in a café. It could be inferred that choosing cafés as an ILS gave positive feeling of relaxation to the students.

\section{Relationship Between Latent Dimensions}

Regression analysis was conducted to see the relationship between each of the factors that influenced the research, namely the student's motivation to use a café, the spatial characteristics of a café, to the student's responses. Figures in bold indicate the two factors show a significant relationship (significance values with $\mathrm{P} \leq 0.05$ ). The names of the factors described in accordance with the table numbers above are as follows 7 .
Table 7 shows dimensions that have an effect on student's learning responses. Student's cognitive responses were mainly affected by their motivation for restoration, productivity, social identity, economic price, and café's amenity quality, along with its naturalness. On the other side, student's motivation for restoration, productivity, novelty, and café's amenity quality along with the presence of student's peer, affected the student's moods and feelings during their informal learning process inside a café. Both motivation for restoration and productivity seem to be the 2 most driven surge students felt in choosing café as an ILS. As for its spatial characteristic, a café's amenity quality holds an important point to make the culinary space into a new space suitable for learning. The presence of amenities in the form of furniture, the size of the study area, lighting conditions, musical atmosphere, and artificial ventilation conditions were found significant to affect the cognitive and affective response, whether it's directly or indirectly. This finding helps the justification of Temple (2006) which states that learners who are happy with their learning space will have better understanding of the study material.

The view that working in a café can increase productivity is similar to some researches on coworking space. This research shows how the use of co-working space by freelancers with different back- 
grounds prefers to find a place to work where they can feel the work environment and are supported by facilities to interact (Bueno, 2018). In this case, students can be said to have the intention of visiting a café with the same purpose. The motivation of student visits to get a restorative feeling is similar to the researches done by Hunter (2014) and Harrop-Turpin (2013). Students tend to look for ILS that can provide a relaxed feeling, which is generally seen as a way for students to balance their feelings after studying on campus. The motivation of students to find cheap product value can be related to how the cafés found tend to have cooperation with online payment partners.

This finding also found the aspect of café amenity as an important factor influencing students' comfort and thought processes. In general, amenities tend to affect the feelings rather than the thinking abilities of students. The findings regarding the safety factor can be a consideration for café owners / managers to develop the place if they want to accommodate student learning needs. This shows the greater role of the architect/designer in managing furniture, lighting quality, comfort temperature, sound, and the size of ILS provided.

The explanation above is similar to the findings by Beckers (2016) who found that preference for using student learning spaces tends to be done to obtain effectiveness. The selection of students to use the café as a study room can also be interpreted that students consider the amenities available in the café to be more promising than those provided in their campuses. This implies that the university has not been able to provide a satisfactory learning space.

The role of cafés to maintain a stable atmosphere for students working in these places can be understood as café neutrality. In the book The Great Good Place written by Oldenburg (1989), one important factor for a third place is that the place must be neutral. In this case, café can be seen as the third place which neutralizes the feeling of fatigue of the students with the products and atmosphere offered. Café is seen as a place to restore the negative feelings felt by students while on campus as their workspaces (second place) in addition to being at home/residence (first place).

The use of cafés as informal learning spaces itself is not new in the eyes of the community. RosePozos Brewer (2015) briefly recounted her experience in her thesis about how the role of cafés in urban social life. She mentioned that one of the stereotypes of higher education students is working in a café, making the coffee shops around the university busy by the activites generated by students. She pointed that students just want to escape routinity from the libraries, the same way professionals also want to get out of the workplace. Through the above explanation, it can be seen that the role of cafés as ILS in this case is as a place of escapism.

On the one hand, students need space to do assignments, prepare for examinations, or work in groups. To accommodate this need, the university provides informal spaces on campus such as student lounges or caféterias. This result can be elaborated like a study conducted by Marcilia (2017), which mentions that a university plaza design can be utilized as an informal study space for students. Specifically, the design can be in the form of seating designs and layout provided in the plaza.

However, students might think that the space within the campus itself is still too "formal" as their ILS, so they need another space outside the university complex as a place that has no formal element. What's more, the time factor offered by cafés gives students the freedom to come at a later time. Limitations of formal education space in providing study space in the afternoon to the evening can be replaced by cafés that are generally open late into the night. With limited formal space or public space with adequate facilities, students do not have many choices for work or interaction, so these activities depend on the accommodation provided by informal spaces. In the case of students and their learning needs, this is replaced by the role of the café.

\section{CONCLUSION}

The study found 6 students' motivation in using cafés as ILS which was referred to from one's shopping motivation. These motivations are restoration, productivity, social identity, novelty, economic value of products, and social interaction. These six findings can be used as a reference for further research involving informal learning and further elaboration to strengthen student learning motivation in informal spaces based on shopping motivation.

ILS characteristics are divided into 2 groups, namely physical and social characteristics. This study found 4 physical characteristics and 3 social characteristics of cafés as an ILS that can influence the learning process of students in it. The physical characteristics of the café as an ILS are the availability and quality of the ambient, café interior design, café ICT facilities, and café naturalness. The social characteristics of cafés as ILS are the ease of student's personalization, the presence of friends, and the presence of customers.

The regression analysis shows that the role of strong internal encouragement from students will spur them to obtain good learning outcomes. The 
motivations for seeking restorative feelings and productivity for the students were found to be significant. On the other hand, the study found that the role of availability and quality of the amenities provided by cafés provided an external impetus for students to use cafés as ILS. The finding suggest positive influence from the café's amenities to the feelings of students, so students are expected to provide good learning performance because they feel happy while using the café as an ILS.

The findings indicate that café space outside the institution is an ILS option for students. The informal space in the form of a place to eat and drink (food and beverages) can be utilized by the institution capable of developing a new study room with a caféteria type. The prospects of retail and commercial spaces that have the potential proximity to a university, can be developed as a café if we want to target students as their buyers. This consideration is taken based on the limited availability of time and place that can be accommodated by universities, so as to meet the learning needs of students to study until late at night.

\section{ACKNOWLEDGMENT}

Author would like to thank Bandung Institute of Technology for supporting this paper through the research funding. Further, Erika Yuni Astuti and Endang Triningsih for providing further assistance in analysis and discussion, RMI Sosrowinarsito for proofreading the English text, and many thanks to all students who were willing to fill out the questionnaire.

\section{NOTES}

1. Data of café in Bandung City were archived from Bandung Department of Culture and Tourism, Ahmad Yani Street no.227, Babakan Surabaya, Kiaracondong, Cihapit, Bandung, West Java 40281 on 1 Februari 2019.

2. Adjustment of questionnaire questions from the preceeding research to the this current research were made as follows:

Taking a stroll in mall is like a recreation $\rightarrow$ Studying in a café is like recreation.

3. Ranking of the institutions were based on accreditation made by Indonesia National Agency of Accreditation for Higher Education Institution (BAN-PT, Badan Akreditasi Nasional Perguruan Tinggi). The accreditation to the institutions were done from 2015-2017.

\section{REFERENCES}

Abeysekera, L. \& Dawson, P. (2015). Motivation and Cognitive Load in the Flipped Classroom: Definition, Rationale and a Call for Research. High Education Research Development, 34, 114.

Arnold, M. J. \& Reynolds, K. E. (2003). Hedonic Shopping Motivations. Journal of Retailing, 79, 77-95.

Astuti, S. (2015). Visual Character Preference for Restaurant \& Café in North Bandung \& Nearby Areas. Institut Teknologi Bandung.

Barrett, P., Davies, F., Zhang Y., \& Barrett L. (2015). The impact of classroom design on pupils' learning: Final results of a holistic, multi-level analysis. Building and Environment, 89, 118133. DOI: https://doi.org/10.1016/j.buildenv. 2015.02.013

Beckers, R., van der Voordt, T., \& Dewulf, G. (2015). Why do They Study There? Diary Research into Students' Learning Space Choices in Higher Education. Higher Education Research \& Development, 35(1).

Beckers, R., van der Voordt, T., \& Dewulf, G. (2016). Learning Space Preferences of Higher Education Students. Building and Environment, 104, 243-252.

Bickford, Deborah J. dan Wright, David J. (2006). Learning Space: Community: The Hidden Context for Learning. The College at Brockport: State University of New York. Educause.

Bloch, P. H., \& Richins, M. L. (1983). Shopping Without Purchase: An Investigation of Consumer Browsing Behavior. Advances in Consumer Research, 10, 389-393.

Bouncken, R. B., Aslam, M. M., \& Reuschl, A. (2018). The Dark Side of Entrepreneurship in Coworking-Spaces. In book: Inside the Mind of the Entrepreneur. DOI: 10.1007/978-3-31962455-6_10.

Boys, J. (2011). Towards Creative Learning Spaces Re-thinking the Architecture of Post-Compulsory Education. Routledge.

Bueno, Salvador et.al (2018). Coworking Spaces: A New Way of Achieving Productivity. Journal of Facilities Management. DOI:10.1108/JFM01-2018-0006.

Gandini, Alessandro (2015). The Rise of Coworking Spaces: A Literature Review. Ephemera: Theory \& Politics in Organization.

Gantini, Christina (2018). Komodifikasi Rumah Tinggal Hindia Belanda. Institut Teknologi Bandung. 
Harrison, A. (2002). Accommodating the New Economy: the SANE Space Environment Model, J. Corp. Real Estate, 4. 248 - 265.

Harrop, D. Dan Turpin, B. (2013): A Study Exploring Learners' Informal Learning Space Behaviors, Attitudes, and Preferences, New Review of Academic Librarianship.

Harrop, D. \& Turpin, B. (2013) A Study Exploring Learners' Informal Learning Space Behaviors, Attitudes, and Preferences, New Review of Academic Librarianship, 19(1), 58-77, DOI: 10.1080/13614533.2013.740961

Hunter, J. and Cox, A.M. (2014). Learning Over Tea! Studying in Informal Learning Spaces. New Library World, 115 (1-2), 34 - 50.

Jamieson, P. (2008). Creating New Generation Learning Environments on the University Campus. Woods Bagot Research Press.

Kim, H. S. (2005). Utilitarian and Hedonic Shopping Motivations of Market Mavens. Proceedings of the 2005 American Collegiate Retail Association Spring Conference.

Kim, H. S. (2006). Using Hedonic and Utilitarian Shopping Motivations to Profile Inner City Consumers. Journal of Shopping Center Research, 13(1), 57-79.

Kumar, R. (2005). Research Methodology: A Stepby-step Guide for Beginners. Pearson Education Australia.

Kwiatkowski, A. \& Buczynski, B. (2011). Coworking: Building Community as a Space Catalyst. Cohere Coworking: Ft. Collins.

Marchand, G., Nardi, N. M., Reynolds, D., \& Pamoukov, S. (2015). The Impact of the Classroom Built Environment on Student Perceptions and Learning. Journal of Environmental Psychology. DOI: 10.1016/j.jenvp.2014.06.009.

Marcillia, S. R. \& Kesumasari, D. (2017). Students' Sitting Preferences at Plaza In Educational Institution. DIMENSI - Journal of Architecture and Built Environment, 44(2), 179-188.

Oblinger, D. G. (2006). Learning Space: Space as a Change Agent. The College at Brockport: State University of New York. Educause.
Oldenburg, R. (1989). The Great Good Place. Da Capo Press.

Pozos-Brewer, R. (2015). Coffee Shops: Exploring Urban Sociability and Social Class in the Intersection of Public and Private Space. Swarthmore College. Dept. of Sociology \& Anthropology: Sociology/Anthropology Senior Thesis.

Solomon, M. R. (2018). Consumer Behavior: Buying, Having, ad Being, 12th edition. ISBN 978-0-13-412993-8. Pearson Education Limited.

Tampubolon, A. C., Farasa, N. \& Kusuma, H. E. (2017). Relationship of Reading Space Preference with Reading Adjustment and Student Thinking Capability. Prosiding Seminar Kearifan Lokal dan Lingkungan Binaan, p. 25-26.

Tampubolon, A. C., \& Kusuma, H. E. (2017). Effects of Reading Motivation and Perceived Quality of the Reading Space on Students' Affective Responses. Journal of Asian Architecture and Building Engineering, 16(3), 559-563. DOI: https://doi.org/10.3130/jaabe.16.559.

Temple, P. (2007). Learning Spaces for the 21st Century. Centre for Higher Education Studies. University of London.

Tiwari, K. R. \& Abraham, A. (2010). Understanding the Consumer Behavior Towards Shopping Malls in Raipur City. International Journal of Manafement \& Strategy.

Turner, J. C. \& Reynolds, K. J. (2010). "The story of social identity". In T. Postmes \& N. Branscombe (eds.). Rediscovering Social Identity: Core Sources. Psychology Press.

Walton, G. \& Matthews, G. Exploring Informal Learning Space in the University: A Collaborative Approach. Routledge

Ward, A. (2018). Exploring Informal Learning Space in the University: Student Perspective. Routledge.

Westbrook, R. A., \& Black, W. (1985). A Motivation-based Shopper Typology. Journal of Retailing, 61, 78-103.

Zwick, W. R., \& Velicer, W. F. (1986). Comparison of five rules for determining the number of components to retain. Psychological Bulletin, 99(3), 432-442. https://doi.org/10.1037/00332909.99.3.432. 